\title{
Reproductive Toxicity Problem Identified
}

National Cancer Institute

\section{Source}

National Cancer Institute. Reproductive Toxicity Problem Identified. NCI Thesaurus. Code C92104.

The device affects reproductive function, embryo development (teratogenicity), and prenatal and early postnatal development. (ISO 10993 part 3) 